ORIGINAL ARTICLE

\title{
IMUNOHISTOKIMIA PADA KONDILOMATA AKUMINATA
}

\author{
,Meidyta Sinantryana Widyaswari ${ }^{1 *}$, Hans Lumintang ${ }^{2}$, Troef Soemarno ${ }^{3}$. \\ ${ }^{1}$ Fakultas Kedokteran Universitas Nahdlatul Ulama Surabaya, Surabaya, Indonesia \\ ${ }^{2}$ Departemen/Staf Medik Fungsional Ilmu Kesehatan Kulit dan Kelamin. Fakultas Kedokteran Universitas \\ Airlangga/Rumah Sakit Umum Daerah Dr. Soetomo Surabaya, Surabaya, Indonesia \\ ${ }^{3}$ Departemen/Staf Medik Fungsional Patologi Anatomi Fakultas Kedokteran Universitas Airlangga/Rumah Sakit Umum \\ Daerah Dr. Soetomo Surabaya, Surabaya, Indonesia \\ *Correspondent Author: drmemed_dyta@unusa.ac.id
}

\section{ARTICLE INFO}

Article history:

Received 23 January 2019

Received in revised form

February 2019

Accepted 4 February 2019

\section{Keywords:}

Condylomata Acuminata,

malignancy,

mmunohistochemistry,

MIB-1(Ki-67),

p16.

\section{Kata Kunci:}

Kondilomata Akuminata,

keganasan,

imunohistokimia

MIB-1(Ki-67),

pl6.

\begin{abstract}
Background: Condylomata Acuminata (CA) is a sexually transmitted disease caused by the Human Papilloma Virus (HPV) type-specific and may be simultaneously co-infected with other HPV types associated with malignancy. Purpose: To differentiate between CA and histopathological of malignancy by immunohistochemistry. LiteratureReview: CA refers to benign epidermal proliferation caused by the HPV types 6 and 11, but co-infection with highrisk HPV types are common. The clinical presentation of CA can't differentiate between benign or preneoplastik diplasia lesions. Koilocytes considered pathognomonic for HPV lesions, these findings sometimes don't appear on $\mathrm{CA}$, and histopathology was not accurate, that immunohistochemistry with MIB-1 (Ki-67) and p16 can beused. Conclusion: Immunohistochemistry examination can help differentiate the diagnosis between malignancy or nonmalignancy in the case of CA.
\end{abstract}

\begin{abstract}
ABSTRAK
Latar Belakang: Kondilomata Akuminata (KA) merupakan penyakit menular seksual yang disebabkan Human Papilloma Virus (HPV) tipe tertentu dan mungkin dapat terinfeksi secara bersamaan dengan tipe HPV lain yang terkait dengan keganasan. Tujuan: untuk membedakan gambaran histopatologi antara KA dan keganasan dengan pemeriksaan imunohistokimia. Telaah Kepustakaan: KA mengacu pada proliferasi epidermal jinak yang disebabkan HPV tipe 6 dan 11, tapi ko-infeksi dengan HPV tipe risiko tinggi sering terjadi. Gambaran klinis pada KA tidak dapat membedakan lesi jinak dari preneoplastik atau lesi diplastik. Koilositosis dianggap patognomonik lesi HPV, temuan ini kadang-kadang tidak tampak pada KA, dan histopatologi tidak tepat, sehingga dapat menggunakan pemeriksaan imunohistokimia dengan biomarker MIB-1(ki-67) dan p16. Kesimpulan: Pemeriksaaan imunohistokimia dapat membantu mendiagnosis banding pada kasus KA yang samar-samar maupun keganasan.
\end{abstract}

\section{PENDAHULUAN}

Kondilomata akuminata (KA), mengingat telah diketahui adanya hubungan antara penyebab KA dengan Human Papilloma Virus (HPV)dengan lesi invasif atau prakanker serviks, vagina, vulva, anus dan penis. ${ }^{1} \mathrm{KA}$ merupakan penyakit menular seksual yang ditandai dengan tumor seperti kutil berwarna seperti daging pada kulit, dapat memberikan gambaran cauliflower pada daerah 
genital yang disebabkan oleh infeksi HPV tipe tertentu. ${ }^{2,3}$ KA umumnya disebabkan oleh HPV tipe 6 atau 11, tetapi dapat juga di sebabkan tipe HPV yang lain, antara lain tipe 16, 18, 31,33 yang biasanya terkait dengan keganasan. ${ }^{2,4}$

Diagnosis KA ditegakkan berdasarkan gambaran klinis dan riwayat yang didapat.Namun, gambaran klinis tidak dapat membedakan lesijinak dari preneoplastik atau lesi displastik.Pemeriksaan histopatologi dapat digunakan untuk menegakkan diagnosis.Meskipun koilositosis dianggap menjadi gambaran patognomonik yang berhubungan lesi pada HPV, temuan ini terkadang tidak tampak pada kondiloma, dan diagnosis histopatologi dapat tidak tepat atau tidak akurat serta banyak pemeriksa patologi memilih untuk mendiagnosa histologis tersebut sebagai lesi samar-samar "konsisten dengan kondiloma". 5

Oleh sebab itu saat ini banyak dikembangkan pemeriksaan,diharapkan mempunyai sensitifitas dan spesifitas yang lebih tinggi yaitu pemeriksaan imunohistokimia yang menggunakan beberapa biomarker yang dapat membantu mendiagnosis dini, menentukan terapi terbaik dan prognosis. Lesi pada HPV menunjukkan peningkatan aktivitas proliferasi dari epitel sel skuamosa dan dapat menjadi keganasan, sehingga kegunaan imunostaining MIB-1(Ki-67) dan p16 sebagai biomarker membantu dalam mendiagnosis banding pada kasus samar-samar dan menguji distribusi HPV yang berisiko rendah dan tinggi-onkogenik pada lesi KA. ${ }^{5,6}$

\section{TELAAH KEPUSTAKAAN}

Kondiloma Akuminatum (KA) merupakan penyakit menular seksual (PMS) yang disebabkan oleh infeksi Human Papilloma Virus (HPV) jenis tertentu, yang ditandai dengan tumor tampak seperti kutil, berwarna seperti daging pada kulit, dapat memberi gambaran cauliflower, fibroepitelioma pada kulit dan mukosa terutama daerah anogenital. KA disebut juga penyakit jengger ayam, kutil kelamin, genital warts. ${ }^{2,3,7} \mathrm{KA}$ mengacu pada proliferasi epidermal jinak atau lesi mukosa yang disebabkan sebagian besar oleh HPV tipe 6 atau 11, tapi ko-infeksi dengan tipe HPV risiko tinggi sering terjadi. ${ }^{7,8}$

Prevalensi infeksi HPV terus meningkat, dikaitkan denganusiayang lebih dini melakukan hubungan awal seksual serta peningkatan gantiganti jumlah pasangan seksual. Infeksi baru akan terjadi pada orang dewasa muda usia 15-24 tahun. Perbandingan insiden laki-laki dan wanita didapatkan 1:1,4. ${ }^{2} \mathrm{KA}$ bersifat asimptomatis. HPV tipe 6 dan 11 bertanggung jawablebih dari $90 \%$ dari KA. ${ }^{7,8}$ Pada penelitian di RSUD Dr. Soetomo Surabaya pada bulan Nopember 2007-Pebruari 2008 didapatkan HPV-16(risiko tinggi)pada lesi genital wanita penderita kondilomata akuminata sebesar $42,9 \%$. ${ }^{9}$ Pada literatur menyebutkan bahwa sekitar 30\% wanita dengan kondilomata akuminata pada daerah vulva dan perianal menunjukkan gambaran cervical intraepithelial neoplasia (CIN) pada hasil sitologinya. ${ }^{10}$

Penyebab dari KA adalah infeksi HPVyang bermultiplikasi di nukleus dari sel epitel yang terinfeksi.Virus ini termasuk dalam kelompok Papoviridae, tidak mempunyai envelopes, berbentuk kapsid icosahedral dengan ukuran diameter 50-55 nmdan tesusun dari double stranded yang panjangnnya 8-kbp molekul DNA. HPV tersebar luas, dapat menginfeksi epitel skuamosa dari kulit dan membran mukosa. ${ }^{2,11,12}$

Telah diketahui bahwa ada hubungan antara infeksi HPV tipe tertentu pada genital dengan terjadinya karsinoma serviks. Berdasarkan kemungkinan terjadinya dysplasia epitel dan keganasan, tipe-tipe yang menginfeksi mukosa genital yaitu HPV tipe 6 dan 11 (low-risk) dan tipe 16 dan 18 (high-risk). High-risk berhubungan dengan kanker serviks, vulva, vagina, penis, dan anus sedangkan low-risk virus berhubungan dengan 
kondiloma akuminata (genital warts) atau lowgrade squamous intraepithelial neoplasia. ${ }^{6,11}$

Penularannya melalui kontak seksual, baik genital, oral maupun anal. Permukaan mukosa yang lebih tipis lebih susceptible untuk inokulasi virus sehingga mikroabrasi pada permukaan epitel memungkinkan virion dari pasangan seksual yang terinfeksi masuk ke dalam lapisan sel basal pasangan yang tidak terinfeksi. ${ }^{2}$ Sel basal merupakan tempat pertama infeksi HPV sehingga setelah inokulasi melalui trauma kecil, virion HPV akan masuk sampai lapisan sel basal epitel. Agar dapat menimbulkan infeksi, HPV harus mencapai epitel yang berdiferensiasi sedangkan sel basal relative undifferentiated, mereka hanya terstimulasi untuk membelah secara cepat sehingga disini hanya terjadi ekspresi gen HPV. Sesuai dengan pembelahan sel basal, virion HPV akan bergerak ke lapisan epidermis yang lebih atas. Dan hanya lapisan epidermis di atas lapisan basal yang berdiferensiasi pada tahap lanjut, yang dapat mendukung replikasi virus.Ekspresi gen virus pada lapisan ini diperlukan untuk menghasilkan kapsid protein dan kumpulan partikel virus.Setelah proses replikasi virus selesai, terjadilah pelepasan virus bersama dengan sel epitel yang deskuamasi, kemudian virus baru akan menginfeksi lapisan basal yang lain. Waktu infeksi HPV sampai pelepasan virus baru adalah 3 minggu (masa inkubasi 3 minggu sampai 8 bulan), rata-rata selama 2-3 bulan. ${ }^{2,3,11}$

KA pada umumnya asimptomatis.Sering timbul di daerah yang lembab dan juga pada daerah yang mudah mengalami trauma pada saat hubungan seksual.KA lesi awalnya kecil, nondistinctive 1$2 \mathrm{~mm}$ papula seperti daging berwarna kulit, multiple atau bervariasi dalam ukuran dan dapat tumbuh menjadi besar beberapa inci dalam diameter, eksofitik seperti kembang kol. ${ }^{7,8}$ Morfologinya KA dapat berbagai bentuk, meskipun perlu diingat bahwa tidak ada batasan yang jelas antara bentukbentuk KA tersebut dan sering pula dijumpai bentuk-bentuk peralihan, yaitu bentuk akuminata, bentuk papul halus (smooth popular form/sessile), bentuk keratotik yang mirip dengan common warts atau keratosis seboroik, dan bentuk datar (flattopped warts). ${ }^{2,3,11}$

Infeksi dapat bertahan sehingga tidak terdeteksi untuk jangka waktu yang lama tanpa manifestasi klinis kutil yang jelas.Setelah manifestasi klinis awal, KA dapat meningkatkandalam jumlah dan ukuran atau sebaliknya, mengalami spontan regresi.Sebagian besar KA akan kambuh dalamtiga bulan, bahkan setelah menjalani terapi. ${ }^{2,3,7}$

Pemilihan pengobatan pada KA sebagian besar berpusat pada menghilangkanlesi yang tampak, mengurangi keluhan dan gejala tetapi tidak dapat mengeradikasiinfeksi virus yang mendasarinya. Berbagai macam terapi yang digunakan sangat bervariasi sehubungan dengan lokasi, ukuran, jumlah, tipe kutil, usia, kerjasama pasien, biaya, efek samping, dosis, durasi pengobatan, dan efektivitas keseluruhan. Meskipun berbagai macam pengobatan mampu pemberantasan jangka pendek, bukti klinis menunjukkan bahwa tetap sebagian besar tidak efektif dalam mencapai pemberantasan kutil jangka panjang, dengan tingkat kekambuhan rata-rata berkisar antara 30 sampai $70 \%$ dalam 3 sampai 6 bulan pertama. ${ }^{2,3,4}$ Demikian pula, tidak mungkin bahwa pengobatan pada KA yang tersedia memainkan peran penting dalam menghentikan atau menunda perkembangan kutil kearah keganasan.Tidak ada terapi definitif yang digunakan sebagai standar ideal pada pengobatan kutil genital dan pemilihan terapi biasanya disesuaikan dengan tujuan dan kebutuhan masingmasing pasien tertentu.Beberapa modalitas terapi pada KA termasuk topikal atau tindakan bedah. Terapi topikal meliputi podophyllotoxin, imiquimo krim, trikloroacetic acid (TCA), 5-fluorourasil (FU) dan injeksi interferon. Sedangkan terapi bedah meliputi bedah beku,kuretase, bedah listrik, 
eksisi dan laser. Terapi dengan pembedahan umumnya dilakukan pada pasien dengan lesi besar dan luas. ${ }^{2,3,4,7,8}$

Pencegahan infeksi HPV yaitu dengan menghindari kontak langsung dengan virus, dan mengubah perilaku seksual dengan melakukan hubungan seksual satu orang (monoghami) yang diketahui kesehatannya serta penggunaan kondom dapat melindungi dan menurunkan resiko infeksi HPV, meskipun pada beberapa penelitian dikatakan masih kontroversial. ${ }^{11,12,13}$ Pemberian vaksin dapat juga mencegah infeksi pada HPV. Terdapat dua vaksin, yaitu: Vaksin HPV bivalen (mencegah infeksi HPV tipe 16 dan 18) dan vaksin HPV kuadrivalen (mencegah infeksi HPV tipe 6, 11,16, dan 18). Idealnya diberikan pada saat menjelang memasuki usia seksual aktif. ${ }^{711,12}$

Diagnosis kondilomata akuminata dapat ditegakkan oleh pemeriksaan klinis dan riwayat yang didapat. Pemeriksaan histologist dapat digunakan untuk menegakkan diagnosis.Namun terkadang, pemeriksaan histopatologi diperlukan yaitu pada keadaan diagnosa yang tidak pasti, tidak membaik dengan terapi standar, penyakit memburuk selama terapi, dan lesi yang atipik.Dalam kasus yang subklinis, penggunaan larutan asam asetar 3-5 \% (tes acetowhite) mungkin membantu dalam memperkuat visualisasi lesi kutil pada genital, menimbulkan perubahan warna menjadi putih hal ini dapat membantu deteksi infeksi KA pada mukosa. Namun prosedur ini tidak spesifik untuk infeksi HPV.Ada juga pemeriksaan Kolposkopi yang berguna untuk melihat lesi KA subklinis, dan kadang-kadang dilakukan bersama dengan tes asam asetat. Namun pemeriksaan ini, belum digunakan secara luas di bagian penyakit kulit. $2,3,7,8,12$

Ciri khas gambaran histopatologi dari sel yang terinfeksi HPV adalah pengembangan dari morfologi keratinosit atipikal yang dikenal sebagai koilocytes.Koilocytes adalah sel yang membesar eksentrik, inti piknotic yang dikelilingi oleh suatu halo perinuklear. Pada umumnya, epidermis akan menunjukkan akantosis ditandai dengan berbagai tingkat papillomatosis, hiperkeratosis, dan parakeratosis serta penipisan atau hilangnya lapisan granular. Rete ridgescenderung memanjang dan menunjuk ke arah dalam dermis, dan pada dermis akan tampak vaskularisasi meningkat dengan kapiler trombosis. ${ }^{7,10,12,14 .}$
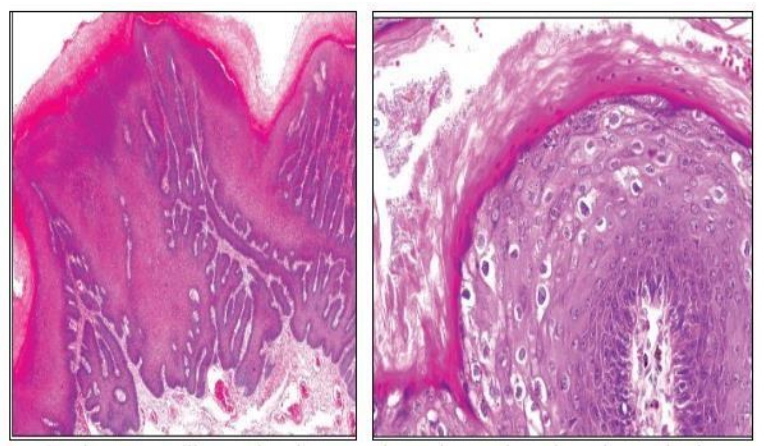

Gambar 1. Kondiloma Akuminatum. Akantosis prominen, hyperkeratosis, dan pemanjangan rete ridgesdan gambaran koilositosis. ${ }^{10}$

Pemeriksaan imunohistokimia adalah suatu metode untuk mengidentifikasi komponen jaringan tertentu dengan cara menginteraksikan antara antigen target dengan antibodi spesifik yang telah diberi label, untuk mengetahui keberadaan suatu antigen serta lokasinya secara spesifik pada jaringan atau sel berdasarkan pada reaksi pengenalan antigen-antibodi. Interaksi antigen dan antibodi ini akan memberikan warna yang berbeda dibanding jaringan sekitarnya, dapat melihat distribusi dan lokalisasi dari komponen seluler spesifik diantara sel dan jaringan lain di sekitarnya. ${ }^{15}$ Teknik imunohistokimia bermanfaat untuk identifikasi, lokalisasi, dan karakterisasi suatu antigen tertentu, serta menentukan diagnosis, terapi, dan prognosis kanker. ${ }^{16}$ Terdapat beberapa metode pengecatan pada imunohistokimia, yaitu metode langsung (direct method), yang menggunakan antibodi primer yang sudah terlabel dan berikatan langsung dengan antigen target secara langsung, metode pengecatan satu langkah karena hanya melibatkan satu jenis antibody yang berlabel; metode tidak langsung (indirect method), 
yang menggunakan dua macam antibodi, yaitu antibodi primer (tidak berlabel) dan antibodi sekunder (berlabel); metode peroksidase-antiperoksidase (PAP), yang menggunakan tiga molekul peroksidase dan dua antibodi yang membentuk seperti roti sandwich; dan metode Avidin-Biotin-Complex (ABC), yang menggunakan afinitas terhadap molekul avidinbiotin oleh tiga enzim peroksidase. ${ }^{17}$

MIB-1 merupakan antibodi monoklonal dengan protein Ki-67 nonhistone nuclear diekspresikan sepanjang siklus mitosis, dengan pengecualian pada fase G0.Antibodi MIB-1 mendeteksi antigen Ki-67 dalam fase G1, S, G2 dan M tetapi tidak pada fase G0 ${ }^{5,18,19}$ Selama interfase, antigen ini dapat secara eklusif ditemukan pada nukleolus, selama mitosis, sebagian besar protein direlokasikan pada permukaan kromosom. Oleh karena infeksi HPV menyebabkan peningkatan proliferasi sel epitel dalam jaringan yang terinfeksi, meningkatnya pewarnaan Ki-67 dapat menjadi cerminan dari infeksi HPV dan luasnya pewarnaan Ki-67 pada umumnya bersamaan dengan meningkatnya grade pada dysplasia. ${ }^{18,19}$ MIB-1 positif pada KA ditemukan secara eksklusif tampak prominen, ekspresi difus dalam inti parabasal dari epitel skuamosa, peningkatan proliferasi aktivitas sel-sel skuamosa dan perluasan sel sampai lapisan diatas dua pertiga dari ketebalan epitel. ${ }^{5}$ Pada epitel skuamosa dalam kondisi normal, MIB-1 yang positif terbatas pada lapisan selparabasal. ${ }^{20}$

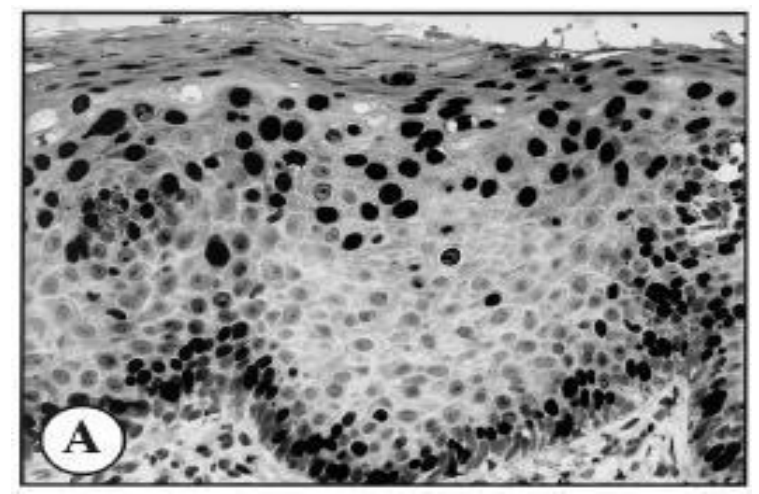

Gambar 2.(A) MIB-1 immunostaining hadir dalam lapisan parabasal diatas dua pertiga pada ketebalan epitel (MIB-1 positif). ${ }^{18}$

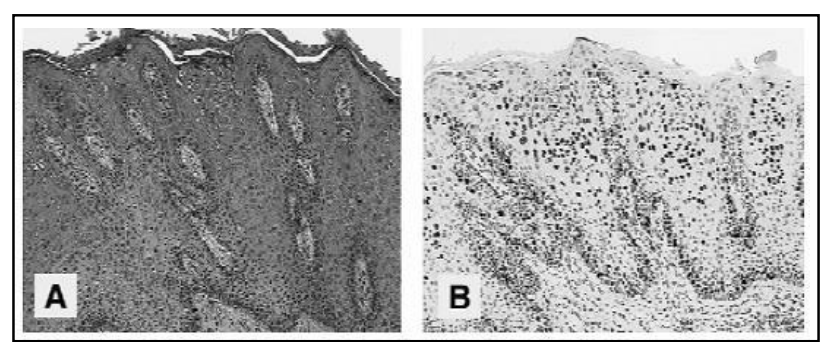

Gambar 3. (A dan B) Gambaran pola pewarnaan imunohistokimia MIB-1 dalam semua kasus KA menunjukkan prominen, ekspresi parabasal yang difus dengan ekstensi dari sel positif dua pertiga atas pada ketebalan epitel. ${ }^{5}$

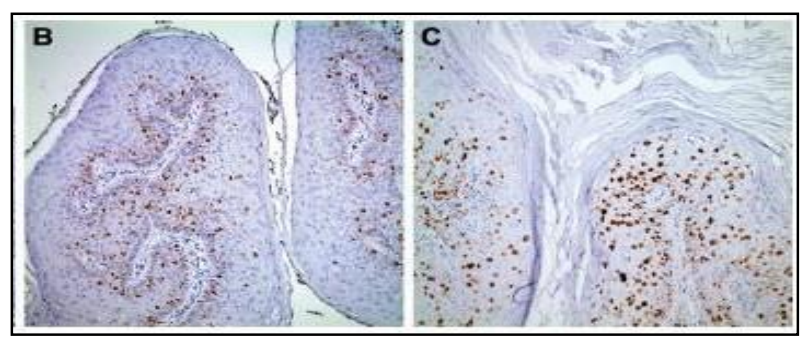

Gambar 4. Imunohistokimia. (B) Ki-67 positif pada epitel basal dalam kondiloma. (C) Ekspresi Ki-67 dalam epitel lapisan atas lebih sering dalam kondiloma dysplasia. ${ }^{14}$

Protein $\mathrm{p} 16$ berasal dari tumour suppressor gene, yang telah diidentifikasi sebagai biomarker untuk infeksi HPV. Peran p16 adalah melakukan siklus sel pada fase G1 dini dan menghambat transisi selanjutnya siklus sel dari G1 ke fase S. Selama fase G1, CDK4 dan CDK6 membentuk kompleks-kompleks dengan cyclin D1 yang kemudian memfosforilasi kelompok protein $\mathrm{Rb}$ yang menghasilkan fosforilasi. Hambatan fosforilasi $\mathrm{Rb}$ menyebabkan pelepasan faktor transkripsi E2F dari kompleks-kompleks $\mathrm{Rb} / \mathrm{E} 2 \mathrm{~F}$.Akibatnya, protein terakumulasi dalam nukleus dan sitoplasma dan dapat dideteksi oleh imunohistokimia. ${ }^{22}$

Ekspresi p16 sering diamati pada HPV risiko tinggi dibandingkan lesi pada risiko rendah.Ekspresi imunohistokimia p16 umumnya terkait dengan HPV onkogenik.Pewarnaan nuclear dan sitoplasma yang difus dan kuat biasanya berkorelasi dengan infeksi HPV risiko tinggi. 
Sensitivitas dan spesifisitas p16 immunostaining yang mendekati $100 \%$ untuk mendeteksi HPV yang terkait karsinoma. ${ }^{21} \mathrm{Pada}$ pemeriksaan dengan imunohistokimia, gambaran overekspresi dari p16 ditandai dengan gambaran immunostaining yang kuat dan difus yang biasanya terlihat pada HPV risiko tinggi lesi-lesi pra kanker. Sedangkan pada lesi yang resiko rendah, seperti infeksi HPV 6 dan 11 akan memberikan gambaran immunostainingyang fokal dan lemah biasanya ditemukan pada semua KA. Penelitian lain menunjukkan bahwa pemeriksaan p16 selalu memberikan gambaran negatif pada jaringan normal.Penilaian dan interpretasi pewarnaan ekspresi p16 menggunakan kriteria Klaes, yaitu positif, bila terdapat warna coklat pada nukleus dan sitoplasma atau pewarnaan nuclear yang kuat; dan negatif: bila kurang $1 \%$ dari semua selpositif. Sporadis bilahanya beberapa sel yang positif tetapi tidak lebih dari 5\% dari semua sel, fokal bila kelompok kecil sel positif tapi kurang dari $25 \%$ dari semua sel, dengan peningkatan intensitas warna coklat, dan difus bila sel positif lebih dari $25 \%$, dengan intensitas warna coklat sangat meningkat. ${ }^{23}$

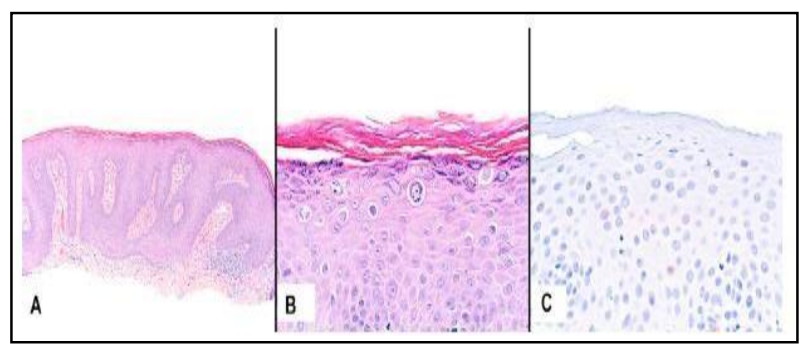

Gambar 5. A. Kondiloma akuminata.

B. Pembesaran, nuclei hiperkromatik koilositosis.

C. Pewarnaan negatif p16 pada sel abnormal menetapkan sifat non-neoplastik. ${ }^{23}$

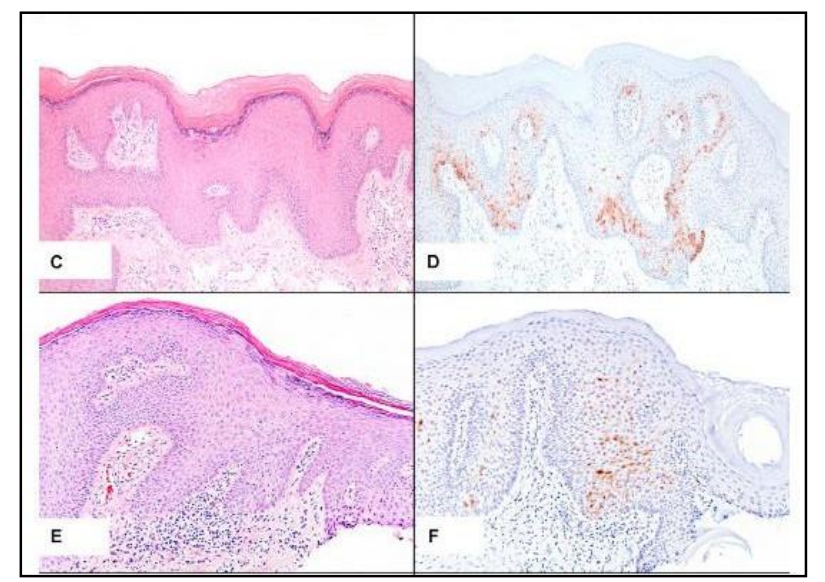

Gambar 6. C dan E. Kondiloma akuminata dengan perilesional kulit.D, Focal positif ekspresi p16 pada kondiloma. F. Ekspresi p16 sporadic pada kondiloma. $^{23}$

\section{PEMBAHASAN}

Kondiloma akuminatum (KA) merupakan penyakit menular seksual pada daerah genital yang disebabkan oleh infeksi Human Papilloma Virus $(H P V)$ jenis tertentu, yaitu tipe 6 dan tipe 11 . Namun, dari beberapa penelitian Pasien dengan KA mungkin dapat terinfeksi secara bersamaan dengan beberapa jenis strain HPV, dan sifat yang penting dari infeksi tersebut dapat menjadi indikator prognostik dari keganasan. HPV dapat menular terutama melalui hubungan seksual.Diagnosis KA dapat ditegakkan berdasarkan gambaran klinis dan riwayat yang didapat.Namun, gambaran klinis tidak dapat membedakan lesi jinak dari preneoplastik atau lesi displastik.

Penilaian akurasi diagnostik pada KA walaupun dapat dilakukan dengan deteksi HPV dengan PCR, teknik ini telah dibatasi penggunaan klinisnya karena prosedur dan biaya yang tinggi.Secara morfologis pada lesi yang ambigu atau meragukan, diagnosis definitif yang terbaik dapat dibuat melalui pemeiksaan histopatologi dan imunohistokimia.Lesi harus diperiksa untuk adanya perubahan menjadi keganasan. Jika diduga neoplasia, atau, setidaknya, diferensiasi virus berisiko rendah atau berisiko tinggi, sehingga 
penggunaan teknik yang tepat sangat dibutuhkan. Teknik imunohistokimia yang menggunakan beberapa biomarker bermanfaat untuk identifikasi, lokalisasi, dan karakterisasi suatu antigen tertentu, serta menentukan diagnosis, terapi, dan prognosis kanker.Penggunaan MIB-1, sebuah penargetan antibodi proliferasi sel protein Ki-67, dapatmembantu dalam melihat adanya infeksi virus.Positif pada KA ditemukan secara eksklusif tampak prominen, ekspresi difus dalam inti parabasal dari epitel skuamosa, peningkatan proliferasi aktivitas sel-sel skuamosa dan perluasan sel sampai lapisan diatas dua pertiga dari ketebalan epitel.Penggunaan p16 (tumour suppressor gene) pada HPV resiko tinggi akan memberikan gambaran overekspresi pada lesi pra kanker ditandai dengan gambaran immunostaining yang kuat dan difus. Sedangkan pada lesi beresiko rendah, seperti infeksi HPV 6 dan 11 akan memberikan gambaran immunostaining yang fokal dan lemah.

Dengan adanya pemeriksaan histopatologi dan imunohistokimia MIB-1(Ki-67)dan p16 tersebut dapat membantu menegakkan diagnosis pada kasus KA yang meragukan atau yang dapat berkembang menjadi keganasan. Oleh karena itu, dengan ditegakkannya diagnosis secara dini dapat memastikan pemberian pengobatan dan dapat mencegah serta menghindari penyebaran penyakit tersebut.

\section{DAFTAR PUSTAKA}

1. Hakim L. Epidemiologi Infeksi Menular Seksual. Dalam: Daili SF, Makes BIB, Zubier F. Editor: Infeksi Menular Seksual. Ed.4. Jakarta: Fakultas Kedokteran Universitas Indonesia; 2011. Hal:11.

2. Murtiastutik D. Kondiloma akuminata. Dalam: Barakbah J, Lumintang H, Martodiharjo S. Editor: Buku Ajar Infeksi Menular Seksual. Surabaya: Airlangga University Press; 2008. Hal:165-169.
3. Zubier F. Kondilomata akuminata. .Dalam: Daili SF, Makes BIB, Zubier F. Editor: Infeksi Menular Seksual. Ed.4. Jakarta: Fakultas Kedokteran Universitas Indonesia; 2011. Hal:140-145.

4. Centers For Disease Control and Prevention. Sexually Transmitted Diseases Treatment Guidelines 2010. Morbidity and Mortality Weekly Report 2010; 59: 69-78.

5. Pirog EC, Chen YT, Isacson C. MIB-1 Immunostaining is a Beneficial Adjunct tes for Accurate Diagnosis of Vulvar Condyloma Acuminatum. Am J Surg Pathol. 2000; 24(10): 1393-1399.

6. Moyer VA. Screening for Cervical Cancer: U.S. Preventive Services Task Force Recommendation Statement. Annals of Internal Medicine 2012; 156 (12): 880-91.

7. Patel RV, Yanofsky VR, Goldenberg G. Genital Warts: A Comprehensive Review. J Clin Aesthet Dermatol. 2012; 5(6): 25-36.

8. Yanofsky VR, Linkner RV, Pompei D, Goldenberg G. Current Update on the Treatment of Genital Warts. Expert Rev Dermatol. 2013; 8(3): 321-332.

9. Hidayati AN, Ervianti E, Lumintang H.Human Papillomavirus (HPV) tipe 16 Pada Lesi Genital dan Serviks Penderita Kondiloma Akuminata. Berkala Ilmu Kesehatan Kulit dan Kelamin 2009; 21 (1): 25-30.

10. Cardoso JC, Calonje E. Cutaneous manifestations of Human Papillomaviruses: A review. Acta Dermatoven. 2011: 145-154.

11. Winer RL, Koutsky LA. Genital Human Papillomavirus Infection. In: Holmes KK, Sparling PF, Lemon SM, Stamm WE, Piot P, Wasserheit JN, editors. Sexually Transmitted Disease $4^{\text {th }}$ edition. New York: Mc Graw Hills; 2008. p. 489-501.

12. Androphy EJ, Kirnbauer R. Human Papiloma Virus Infections. In : Wolf K, Goldsmith L, Katz S, Gilchrest B, Paller A, Leffell O, editors. Fitzpatrick's Deramtology in General Medicine. $8^{\text {th }}$ ed.New York: McGrawHill;2012.p.2421-33.

13. Sadan O, Bilevsky E, Shejter E, Levy T, Bachar $\mathrm{R}$, Yarden H, et.al. Occurrence of cervical 
intraepithelial neoplasia in generally healthy women with exophytic vulvar condyloma acuminata. Inf Dis Obst Gynec 2005; 13(3): 141-143.

14. Baydar DE, Kulac I, Ozagari A, and Tezel GG. Occurrence of Dysplasia and Human Papilloma Virus Typing in Penile Condyloma. Urology. 2013: 9-15.

15. Jackson P, Blythe D. Immunohistochemical Techniques. In: Bancroft J, Gamble M, editors. Theory and practice of Histological Techniques. Elsevier. 2008.

16. Boenisch T. Handbook: Immunochemical Staining Methods. California: Dako Cooperation. 2001.

17. Mashhood AA. Importance of immunohistochemistry in the diagnosis of skin tumours. Journal of Pakistan Association of Dermatologist 2008; 18: 1-3.

18. Logani S, Lu D, Quint WGV, Ellenson LH, Pirog EC. Low-Grade Vulvar and Vaginal Intraephitelial Neoplasia: Correlation of Histologic Features with Human Papillomaviru DNA Detection and MIB-1 Immunostaining. Mod Pathol. 2003;16(8): 735-741.

19. Atirici SD, Imir G, Ozer H, Elagoz S, Simsek G, Cetin M. Evaluation of Ki-67 Immunostaining in the Diferrential Diagnosis of Low Grade Squamous Intraepthelial Lesion and Normal Cervix. J Turkish-German Gynecol Assoc. 2007: 285-289.

20. Miller RT. Utility of Ki-67(MIB-1) Immunostaining in Cervical Biopsies. Propath. 2002.

21. Maniar KP, Ronnet BM, Vang R, and Yemelyanova A. Coexisting High-Grade Vulvar Intraepithelial Neoplasia (VIN) and Condyloma Acuminatum-Independent Lesions Due to Different HPV Types Occuring in Immunocompromised Patients. Am J Surg Pathol. 2013; 37(1): 53-60.

22. Agarwal P, Kabir FML, DeInnocentes P, Bird RC. Tumor Suppressor Gene p16/INK4A/CDKN2A and Its Role in Cell Cycle Exit, Differentiation, and Determination of Cell Fate. In: Cheng P, editor. Tumor Suppressor Genes. InTech. 2012. http://www.intechopen.com/books/tumorsuppressor-genes.

23. Kazlouskaya V, Shustef E, Allam SH, Lal K, and Elston D. Expression of p16 protein in lesional and perilesional condyloma acuminate and bowenoid papulosis: Clinical significance and Diagnostic implications. J Am Acad Dermatol. 2013; 69: 444-9. 